\title{
Determinants and predictability of global wildfire emissions
}

\author{
W. Knorr ${ }^{1}$, V. Lehsten ${ }^{1}$, and A. Arneth ${ }^{2,1}$ \\ ${ }^{1}$ Physical Geography and Ecosystem Analysis, Lund University, Sölvegatan 12, 22362 Lund, Sweden \\ ${ }^{2}$ KIT/IMK-IFU, Kreuzeckbahnstr. 19, 82467 Garmisch-Partenkirchen, Germany
}

Correspondence to: W. Knorr (wolfgang.knorr@gmail.com)

Received: 2 December 2011 - Published in Atmos. Chem. Phys. Discuss.: 6 February 2012

Revised: 8 June 2012 - Accepted: 23 July 2012 - Published: 1 August 2012

\begin{abstract}
Biomass burning is one of the largest sources of atmospheric trace gases and aerosols globally. These emissions have a major impact on the radiative balance of the atmosphere and on air quality, and are thus of significant scientific and societal interest. Several datasets have been developed that quantify those emissions on a global grid and offered to the atmospheric modelling community. However, no study has yet attempted to systematically quantify the dependence of the inferred pyrogenic emissions on underlying assumptions and input data. Such a sensitivity study is needed for understanding how well we can currently model those emissions and what the factors are that contribute to uncertainties in those emission estimates.

Here, we combine various satellite-derived burned area products, a terrestrial ecosystem model to simulate fuel loads and the effect of fire on ecosystem dynamics, a model of fuel combustion, and various emission models that relate combusted biomass to the emission of various trace gases and aerosols. We carry out simulations with varying parameters for combustion completeness and fuel decomposition rates within published estimates, four different emissions models and three different global burned-area products. We find that variations in combustion completeness and simulated fuel loads have the largest impact on simulated global emissions for most species, except for some with highly uncertain emission factors. Variation in burned-area estimates also contribute considerably to emission uncertainties. We conclude that global models urgently need more field-based data for better parameterisation of combustion completeness and validation of simulated fuel loads, and that further validation and improvement of burned area information is necessary for accurately modelling global wildfire emissions. The results are important for chemical transport modelling studies, and for simulations of biomass burning impacts on the atmosphere under future climate change scenarios.
\end{abstract}

\section{Introduction}

Wildland fires have an important impact on the atmospheric load of trace gases and aerosols, on air pollution, and climate (Seiler and Crutzen, 1980; Langmann et al., 2009). Fire has also been recognized as an important agent in the workings of the Earth system, because it is an intrinsic feature of most terrestrial ecosystems and responds both to climate change and human intervention (Bowman et al., 2009; Arneth et al., 2010). In response, comprehensive datasets have been developed that characterize the extent of fires globally from satellite data (Grégoire et al., 2003; Simon et al., 2004; Roy et al., 2005; Mouillot and Field, 2005; Giglio et al., 2006, 2010; Tansey et al., 2008), as well as the chemical emissions from those fires (Schultz, 2002; Duncan et al., 2003; Hoelzemann et al., 2004; van der Werf et al., 2006, 2010; Schultz et al., 2008; Mieville et al., 2010). Those data sets can be used to study the effects of wildfires on air pollution and climate (Langmann et al., 2009), while others that differentiate between types of biomass burning sources are also useful for better characterizing the role of fires in the Earth system (e.g. van der Werf et al., 2010).

The next step forward will be to assess the possible future and (pre-instrumental) past impact of wildfires under the conditions of a changing climate. In contrast to the emission studies cited above, such an approach requires the use of a fully prognostic model of wildfire occurrence, which includes using a dynamic vegetation model for predicting the accumulation of fuels, to replace the use of satellite remote sensing data. However, while global dynamic vegetation models exist on a global scale that have been coupled to predictive fire models (Thonicke et al., 2001, 2010; Arora and Boer, 2005; Prentice et al., 2011), a comparison of simulated fractional area burned with those inferred from satellite 
data still shows large discrepancies (Thonicke et al., 2001, 2010; Prentice et al., 2011).

Before including fire in comprehensive Earth system models, it is necessary to assess our current ability to model the different steps necessary for computing chemical emissions from wildfires. These steps include characterization of area burned, quantification of the amount of biomass combusted per area burned, and amount of chemical species emitted per unit amount of biomass combusted. Only if we better understand how sensitive simulated emissions are to uncertainties in each of these steps can we, for example, judge how well we need to reproduce burned area by prognostic models, or how accurately we need to simulate fuel loads and combustion factors.

The commonly used approach to compute pyrogenic emissions is to combine information on fire occurrence and extent with information on available fuel, combustion completeness (i.e. fraction of fuel combusted in a fire), and conversion rates of combusted fuel to the emitted amounts of various trace gases (Seiler and Crutzen, 1980). Relevant observations that cover the entire earth are available only from satellite remote sensing. Such products include fire occurrence counts detected by radiant emissions from fires in the middle infrared (Matson and Dozier, 1981), or the detection of burn scars by analysing bidirectional surface reflectance (Govaerts et al., 2002; Roy et al., 2005).

Fuel load is more difficult to derive from remotely sensed information. Studies using radar or LIDAR are promising but rely on locally trained image classification (e.g. Mutlu et al., 2008), or can only sense fuel contained in standing structures (Saatchi et al., 2007). To the knowledge of the authors there is no global product of fuel load available that is based on these techniques. Therefore, ecosystem models are often used to model fuel load (e.g. van der Werf et al., 2010), which depends not only on plant type distribution and climate, but also on the effect of the fires itself (Thonicke et al., 2010). Observations of the combustion process are even more difficult to obtain from the field, with the closest being observations of radiant energy from satellites, which can be used for estimating the total amount of energy generated by the fire (Wooster et al., 2005). Since this technique is still under development (Boschetti and Roy, 2009; Ellicott et al., 2009), the fraction of fuel combusted in a fire is usually an assumed or modelled value (Ito and Penner, 2004; Arora and Boer, 2005; Wiedinmyer et al., 2006; Thonicke et al., 2010).

The provision of emission fields for biomass burning based on global models and satellite observations is already a useful and important step for the atmospheric modelling community. It allows assessing how important pyrogenic emissions are for the total atmospheric trace gas or aerosol load, and their contribution to interannual variations and episodes (Langmann et al., 2010). Modelled trace gas fields can be compared to those trace gases that are easy to observe, such as carbon monoxide, to evaluate chemical transport and emissions modelling together (Langenfelds et al., 2002; Kopacz et al., 2010). However, the variety of approaches to compute emissions leads one to suspect that the use of different observations and models will yield varying emission fields, and any comparison between modelled and observed atmospheric trace gases or aerosol loads needs to take into account that a whole range of possible emission fields exists, some of which may lead to better and some to worse agreement with atmospheric observations. Only if we narrow down uncertainties for simulating current emissions can we hope to develop reliable models for assessing the impact of climate change on these emissions.

In this study, we therefore pose the following question: how sensitive are simulations of chemical emissions from wildfires to varying assumptions and data currently available in the published literature?

\section{Methods}

We combine remotely sensed burned area with modelled fuel loads from the Lund-Potsdam-Jena General Ecosystem Simulator (LPJ-GUESS) (Smith et al., 2001). The flux of carbon from fire to the atmosphere computed by LPJ-GUESS is subsequently fed into a set of separate models to compute emissions of various trace gases (Fig. 1). We explore the sensitivity of modelled chemical emissions to the different algorithms and parameterizations for emissions and fuel combustion, as well as remotely sensed burned area. We also propagate reported uncertainties in emission factors to the final results. Finally, we compare the sensitivity of modelled emissions to uncertainties in emission factors, to the choice of emission model and burned area data set, and uncertainties regarding the parameterisations of fuel combustion and turnover.

The purpose of this work is to explore the sensitivity of modelled wildfire emissions to various key inputs and parameterizations, where these imputs are varied within reasonable bounds based on published data and estimates. This method mainly serves the purpose of pointing out areas that need further refinement or validation. The modelling framework with its associated flow of information is illustrated in Fig. 1.

We deliberately choose a simple approach to fire modelling, instead of a fully prognostic fire model, in order to make the chain of factors entering the sensitivity study as transparent as possible. Instead of computing burned area and assessing how different parameterisations of the burnedarea model affect the results, we use a variety of burned area products as input.

\subsection{Ecosystem and fuel combustion model}

We use LPJ-GUESS to compute the establishment, growth and mortality of potential natural vegetation, as well as plant and soil water status and plant litter accumulation on a global scale (Smith et al., 2001). Carbon, water and surface energy 
Table 1. Plant functional types and fire-related mortality used with LPJ-GUESS.

\begin{tabular}{lcc}
\hline PFT & Shade tolerant & Fire-related mortality \\
\hline Boreal needle-leaved evergreen tree & $\mathrm{x}$ & 0.7 \\
Boreal needle-leaved evergreen tree & & 0.7 \\
Boreal needle-leaved summergreen tree & & 0.7 \\
Temperate broad-leaved summergreen tree & $\mathrm{x}$ & 0.9 \\
Temperate broad-leaved summergreen tree & & 0.9 \\
Temperate broad-leaved evergreen tree & $\mathrm{x}$ & 0.7 \\
Tropical broadleaved evergreen tree & $\mathrm{x}$ & 0.9 \\
Tropical broadleaved evergreen tree & & 0.9 \\
Tropical broadleaved raingreen tree & & 0.7 \\
Cool (C3) grass & & 1.0 \\
Warm (C4) grass & & 1.0 \\
\hline
\end{tabular}

exchanges are computed on a daily time step, while establishment, growth, allocation, mortality by general disturbance and competition are simulated with a yearly time step. We use the global version of LPJ-GUESS with 13 plant functional types (PFTs), comprising nine tree and two grass PFTs (see Table 1). LPJ-GUESS is used in cohort mode, where groups of individuals of similar age and size, or "cohorts" are represented by a single individual. We run LPJ-GUESS with five patches per grid cell, and a stochastic general patch destroying disturbance with an average return interval of $100 \mathrm{yr}$. This general, unspecified disturbance represents other catastrophic events than fire (e.g. windfall or insect outbreaks) to prevent unrealistically high stand ages where no fires occur (Smith et al., 2001).

As input data we use the gridded Climate Research Unit TS3.1 monthly observations of diurnal mean temperature, precipitation and percent of potential (full sunshine) insolation for the period 1901 to 2009 (Mitchell and Jones, 2005; Jones and Harris, 2011), following a spin-up procedure described by Sitch et al. (2003). Annual atmospheric $\mathrm{CO}_{2}$ concentration is derived from ice-core data (Etheridge et al., 1996) and atmospheric measurements obtained at Maona Loa, Hawaii (Keeling et al., 1995). The model is run on a global quasi-1-degree equal-area grid with 10525 nonglaciated land grid points. The grid has a resolution of $1 \mathrm{de}-$ gree latitude by 1 degree longitude at the equator, with the same spacing along lines of equal latitude when away from the equator.

In variation to the standard LPJ-GUESS model, firerelated mortality is computed on a monthly time step by burning each patch with a probability equal to the observed burned fraction of the corresponding grid cell. If a patch burns, a random fraction of the cohorts representing woody PFTs is killed, where the average number of cohorts killed equals the PFT-dependent fire related mortality (see Table 1). Grasses are not killed in a fire but are assumed to re-sprout.

Fuel is represented by four classes: live grass, herbaceous litter (dead grass, leaves or needles), live tree leaves or needles, and woody litter (i.e. dead trees, stems and branches).
Following Lehsten et al. (2009), plant litter, if not consumed by fire, decomposes at differential rates, with a turnover time at $10^{\circ} \mathrm{C}$ of $20 \mathrm{yr}$ for woody litter (Weedon et al., 2009), but $2.83 \mathrm{yr}$ for herbaceous litter as in (Sitch et al., 2003). Based on extensive observations by Shea et al. (1996) from African savannas, we assume that in each burned patch, $100 \%$ of live grass and $66 \%$ of the mass of tree leaves are combusted. The same study reports an average combustion factor for herbaceous fuel (live grass and leaf litter, $c_{\mathrm{h}}$ ) of $0.91 \pm 0.03$ $(n=13)$, and for woody litter $\left(c_{\mathrm{W}}\right)$ of $0.40 \pm 0.08(n=12)$. For the same ecosystem type, Stocks and Kauffman (1997) report an average combustion factor for all fuels of 0.83 ( $n=30$, range 0.44 to 1.00 ). Because the study reports only ranges for groups of samples, we assumed that the mean in each group equals the average of the minimum and maximum, and do not report a standard error estimate. Assuming the ratio of woody to herbaceous fuel is 1:3 (based on Shea et al., 1996), this is consistent with either $c_{\mathrm{h}}=1$ and $c_{\mathrm{W}}=0.32$, or $c_{\mathrm{h}}=0.9$ and $c_{\mathrm{W}}=0.62$, depending on whether we assume a low or a high estimate for herbaceous fuel.

Combustion factors for forests reported by Ito and Penner (2004) average $0.27 \pm 0.04$ for woody ("coarse") and $0.90 \pm 0.04$ for herbaceous ("fine") fuels ( $n=8$; in each case, we give the standard error of the mean). Data given by Stocks and Kauffman (1997) for boreal forests average 0.57 ( $n=21$, range 0.36 to 0.76 ) for total fuel combustion. More data on total combustion factors are available from de Groot et al. (2009) for 128 boreal forest and woodland sites in Canada. From this study, we derive an average combustion factor for total fuel at the forest floor of $0.58 \pm 0.02$. If we assume a herbaceous combustion factor of 0.9 and equal amounts of herbaceous and woody fuel, a value of 0.57 for total combustion factor translates into $c_{\mathrm{W}}=0.24$.

For simplicity, we assume that no live woody plant material is burned in a fire. We also assume that all herbaceous fuel is consumbed $\left(c_{\mathrm{h}}=1\right)$, but define an additional sensitivity run with $c_{\mathrm{h}}=0.9$. This value is similar to the data-based emission model study by Wiedinmyer (2006), who used a value of 0.9 for forested areas and 0.98 for grasslands. 


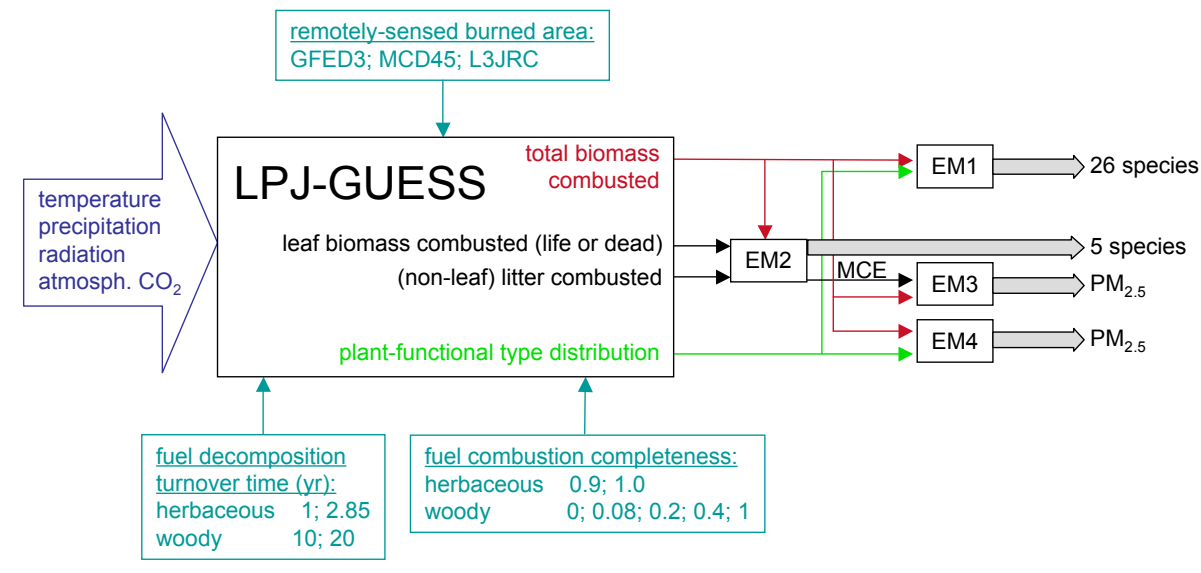

Fig. 1. Flow of information used for the sensitivity analysis (thin arrows) between different models (black rectangles). Fixed inputs to the modified vegetation model LPJ-GUESS in dark blue, variable inputs blue-green, outputs in red, black and green, and emissions shown as grey arrows. MCE: modified combustion efficiency, EM: emission model. $\mathrm{CO}_{2}$ is global and annual mean, climate inputs gridded and monthly.

For the woody combustion factor, $c_{\mathrm{w}}$, we define reasonable bounds between 0.2 based on Ito and Penner (2004), de Groot et al. (2009) and Stocks and Kauffman (1997), and 0.4 based on Shea et al., 1996. To implement woody fuel combustion in LPJ-GUESS, however, the difficulty arises that woody litter in LPJ-GUESS comprises both woody debris on the ground and wood in standing dead trees. The fuel load data reported mostly refer to fuel on the forest floor. Lack of data makes it difficult to apply a suitable correction factor. Therefore, we assume that in an extreme case, half of the woody biomass is in standing trees that do not burn and that the remaining dead woody biomass has a combustion factor of 0.2 . The resulting case with $c_{\mathrm{W}}=0.1$ is used as a further sensitivity test.

In order to assess uncertainties related to the simulation of fuel loads, we adjusted the turnover time of woody litter to approximately match observed woody fuel loads in extratropical forests. The adjustment defined a further parameterisation where the standard turnover time for woody litter was changed from 20 to 4 yr. For this simulation, we use a mid-range woody combustion factor of 0.30 , and the standard herbeceous combustion factor of 1 . The simulated and observed fuel loads are shown in the results section.

The standard LPJ-GUESS model treats leaf, stem and branch turnover at annual time steps. In order to realistically simulate seasonal variations of fuel load, input of dead leaves into the pool of herbaceous litter and the phenology of tropical raingreen trees have been modified according to Lehsten et al. (2009). For summergreen trees, the revised model uses length of day to predict the date of leaf shedding (White et al., 1997). Here, leaves are shed on the first day with length less than $10 \mathrm{~h}$, or after 270 days after leaf shooting when day length is never less than $10 \mathrm{~h}$. In the autumn, a day length of $10 \mathrm{~h}$ occurs between 21 October (Hainich, Germany, deciduous forest, latitude 51.0 ${ }^{\circ}$ ) and 23 November (Goodwin Creek, Mississippi, deciduous forest, latitude $34.3^{\circ}$ ), the approximate latitude range where summergreen trees typically grow. The dates coincide with the time of declining vegetation greenness seen in satellite data for these two sites (http://fapar.jrc.ec.europa.eu/; Gobron et al., 2007). For grasses, the soil moisture triggers of the phenology scheme have also been modified similar to raingreen trees: leaf shoot requires that conditions have been wet for 7 days, while dry conditions for 30 days are sufficient to trigger leaf senescence.

\subsection{Burned area data sets}

We use three global multi-annual data sets of burned area: the global fire emissions database (GFED) version 3 burned area product (Giglio et al., 2010), the Moderate Resolution Imaging Spectroradiometer (MODIS) MCD45 burned area product (Roy et al., 2005), and the L3JRC burned area product (Tansey et al., 2008). GFED3 is a monthly multi-sensor merged product starting in July 1996 and currently ending December 2010 aggregated at $0.5^{\circ}$ resolution, MCD45 a 1-km product from April 2000 until November 2010 with a gap in June 2001 based solely on the series of MODIS sensors, and L3JRC a 1-km product based on the SPOTVEGETATION sensor starting April 2000 and ending March 2007. MCD45 reports up to one burning event per month and grid cell with an accuracy of several days, while L3JRC reports the date of up to one burning event per pixel for the season starting in April and ending in March the following year. From 2001 onwards, GFED3 uses mainly MODIS reflectance data as input, the same as MCD45. All three data sets were aggregated, if necessary, to 0.5 by 0.5 degree spatial resolution, converted to monthly burned fraction of each grid cell and used as input to the modified LPJ-GUESS model. Conversion to the equal-area grid as used by the LPJ-GUESS model was performed by assigning the burned-area grid cell that contains the centre of the corresponding LPJ-GUESS 
grid cell. The gap in June 2000 for MCD45 was filled by using the average burned area for June of all the other years in the data set.

The L3JRC data where found by Chang and Song (2009) and Giglio et al. (2010) to significantly overestimate official fire statistics for boreal North America, and are much higher than GFED3 in the boreal zone as a whole (Giglio et al., 2010). In addition, one atmospheric inversion study by Kopacz et al. (2010) using the older GFED version 2 emission fields as a prior, derived posterior $\mathrm{CO}$ emissions only $25 \%$ higher than GFED2 for boreal North America, where the source is almost entirely from biomass burning. GFED2 burned area is of a broadly similar magnitude to GFED3 in this area. Based on those findings, we need to be cautious about including this data set in the sensitivity analysis. We do include it, however, since MCD45 and GFED3 are derived mostly from the same sensor (MODIS), and because a further published global data set, GLOBCARBON, has similar characteristics to L3JRC (Giglio et al., 2010).

\subsection{Emission models}

The standard approach to modelling emissions from wildfires established by Seiler and Crutzen (1980) is to assign emission factors converting combusted biomass to emissions of chemical species, with different emission factors for different ecosystems. Here, we use the latest compilation of such emission factors by Andreae and Merlet (2001, updated according to P. Merlet personal communication, 2008) as Emission Model 1 (EM1). Emission factors are given in $g$ species per kg dry mass combusted. To convert output from LPJGUESS to dry matter, we assume a carbon content of $50 \%$ for all dry, dead biomass (Ragland and Aerts, 1991). Separate emission factors are given for savanna and grassland, tropical forest, and extratropical forest. We assign these emission factors according to the vegetation simulated in LPJ-GUESS by using the following scheme: the category "savanna and grassland" is defined where the simulated fraction of grass LAI over total LAI is greater than $20 \%$, "tropical forest" where this fraction is less than $20 \%$ and the dominant simulated PFT is a tropical tree, and "extratropical forest" when none of the other conditions is met. EM1 is used to simulate emissions of $\mathrm{CO}_{2}, \mathrm{CO}, \mathrm{CH}_{4}$, non-methane hydrocarbons (NMHCs), total particulate matter (TPM), particulate matter of 2.5 micron and smaller diameter $\left(\mathrm{PM}_{2.5}\right), \mathrm{NO}_{\mathrm{x}}, \mathrm{N}_{2} \mathrm{O}$, $\mathrm{NH}_{3}, \mathrm{SO}_{2}$, organic carbon (OC), black carbon (BC), ethane, propane, $\mathrm{C}_{4}$ and higher alkanes, ethene, propene, $\mathrm{C}_{4}$ and higher alkenes, methanol, ethanol, formaldehyde, acetaldehyde, acetone, benzene, toluene, and xylenes.

An alternative approach to using ecosystem type for differentiating between different emission factors is to model the modified combustion efficiency (MCE) and establish MCE-dependent emission factors. The MCE is defined as the amount of carbon emitted as $\mathrm{CO}_{2}$ divided by the sum of carbon emitted as $\mathrm{CO}$ and $\mathrm{CO}_{2}$. In Emission Model 2 (EM2),
MCE is computed from a linear function of the ratio of combusted woody to grass litter, derived from the data presented by Ward et al. (1996). We decided against using the original non-linear model by Ward et al. (1996), because it predicts $\mathrm{MCE}=0.85$ when all litter is woody, which is much lower than the lowest ecosystem-specific value implied by the data of Andreae and Merlet (2001), which is 0.94 for extratropical forests. Also, Ward et al. (1996) present no data for a woody litter fraction greater than 0.84 (fuel ratio $<0.16$, see Fig. A1). Their original model is based on fuel present at the sites, not the amount of fuel burnt in each fire. To obtain the amount of combusted fuel from their data, we assume that all grass present at the site burns completely, which is supported by a combustion factor of 1.0 for one site where almost all fuel is grass. It is also assumed that the combustion factors of all other fuel types than grass are the same. To obtain combusted woody litter, the combustion factor for fuel other than grass is then calculated from the reported total combustion factor using the equation $C_{\mathrm{n} g} \cdot\left(T^{\prime}-G^{\prime}\right)+G^{\prime}=C \cdot T^{\prime}$, where $C$ is total combustion factor, $C_{\mathrm{n} g}$ non-grass combustion factor, $T^{\prime}$ total fuel present, and $G^{\prime}$ grass fuel present. We then use $L=C_{\mathrm{n} g} \cdot L^{\prime}$ and $G=G^{\prime}$ to obtain combusted woody litter, $L$, and combusted grass, $G$, from woody litter $\left(L^{\prime}\right)$ and grass $\left(G^{\prime}\right)$ present at the site.

The linear model of the modified combustion efficiency derived from combusted fuel amounts is:

$\mathrm{MCE}=0.898+0.062 \cdot G /(G+L)$.

Emission factors as a function of MCE are taken from Ward et al. (1996) for $\mathrm{CO}, \mathrm{CH}_{4}, \mathrm{NMHCs}$ and $\mathrm{PM}_{2.5}$. The equation for NMHCs has been taken from Ward (2001), who cites Ward et al. (1996). We use the definition of the MCE to derive emissions of $\mathrm{CO}_{2}$ from emissions of $\mathrm{CO}$ as $\mathrm{CO}$ emissions times $\mathrm{MCE} /(1-\mathrm{MCE})$ times $44 / 28$, where the latter is the ratio of molar masses of $\mathrm{CO}_{2}$ and $\mathrm{CO}$, respectively.

We use two further models for the emission of $\mathrm{PM}_{2.5}$ based the work of Janhäll et al. (2010). Emission Model 3 (EM3) uses a linear relationship between the emission factor for particle mass and MCE taken from Eq. (10) of Janhäll et al. (2010), using the MCE from EM2 (see Fig. 1). The emission factor for EM3, in g per kg dry mass, is:

$\mathrm{EF}_{\mathrm{PM}_{2.5}}=86.1-85.3 \cdot \mathrm{MCE} \pm 3.1$.

Emission Model 4 (EM4) uses fixed emission factors for aerosol mass differentiated between forest, savanna and grass biomes (Janhäll et al., 2010, Table 4). The values are $11 \pm 6$, $6 \pm 3$ and $5 \pm 2 \mathrm{~g}$ per kg dry mass, respectively. For EM4, the three biomes are determined from the simulated grass fraction of LAI as follows: "forest" for up to $20 \%$, "savanna" for greater than $20 \%$ and up to $80 \%$, and "grass" for greater than $80 \%$.

The data for particle mass used by Janhäll et al. (2010) are for a maximum particle size of either 1 or 2.5 microns, with the majority falling into the $\mathrm{PM}_{2.5}$ category. They report a small impact of using different size classes on their results. 


\subsection{Uncertainties}

We assess the sensitivity of simulated emissions to changing parameters or input data sets by varying them within bounds consistent with available data or published estimates. The resulting uncertainties in emissions are intended as a first indication of their order of magnitude. We therefore neither attempt to rank those uncertainties, nor do we combine them to arrive at an overall uncertainty estimate.

Uncertainties in simulated emissions result from uncertainties in burned area, in the amount of combusted biomass on the burned surfaces, from differences between emission models, and from the uncertainties of the emission factor for a given model. All uncertainties are represented by changing model parameters, except for those resulting from differences in estimated burned area. For this special case, we need to make assumptions about the spatial correlation of the error that leads to the difference between burned-area products. At one extreme, we could assume that they are spatially uncorrelated at the grid cell level, in which case the global uncertainty would be the square root of the summed error variances over all grid cells. At the other extreme, we could compute the standard deviation after forming global sums of each simulation, assuming differences are entirely due to systematic errors. If, however, differences turned out to be purely random and uncorrelated between different grid cells, this latter approach would lead to a large underestimate of the uncertainty.

Here, we assume that the dominant contributing factor to uncertainties are systematic differences between methods of burned-area retrieval, but that the impact of these differences varies regionally. This is supported by the finding that magnitude and sign of differences between L3JRC, MODIS and GFED3 vary substantially between large regions, as does the difference to regional-scale burned-area data (Chang and Song, 2009). Therefore, we compute the uncertainty for each of the GFED basis regions (see Fig. A2) separately, and then use the square root of the squared sum as the global uncertainty estimate. For two regions, Boreal North America and Boreal Asia, we take the absolute difference between simulations with GFED3 and MCD45 as the uncertainty estimate. This is to avoid the extremely high burned areas by L3JRC for those regions. For all the others, we use the sample standard deviation of the three simulations with different burned area products (using $n-1$ in the denominator).

We further use the sample standard deviation, but based on global sums, for emissions of $\mathrm{PM}_{2.5}$, where there are four emission models available. For other species with only two emission models, we indicate the range between the high and the low estimate based on global sums. The same approach is used for indicating the uncertainty due to fuel combustion completeness, where the range between the high $\left(c_{\mathrm{w}}=0.4\right)$ and the low esimate $\left(c_{\mathrm{w}}=0.2\right)$ is taken. This assumes that the impact of uncertainties in $c_{\mathrm{h}}$ on simulated emissions is small. For the uncertainty due to simulated fuel loads, we give the range between the average of the two simulation with woody combustion factor 0.2 and 0.4 and standard turnover time for woody litter on the one hand, and the simulation with adjusted woody litter turnover time and woody combustion factor of 0.3 on the other. While two to four samples are certainly too few to derive a robust margin of error, this study nevertheless attempts to derive a first estimate of the contrasting contributors to uncertainties of wildfire chemical emissions.

To estimate the uncertainties resulting from the finite sample size of emission factors measured in the field, we use the standard deviations of EM1 as reported by P. Merlet (personal communication, 2008), with the following provisions: if error margins are not given (only one or no measurements), we use twice the higher relative standard deviation of the emission factors for the other ecosystems, as far as available, else four times the mean value. If uncertainties are given as a range (when only two measurements are available), we use twice the range. We further assume that the uncertainties of emission factors for different ecosystems are uncorrelated in order to derive spatial integrals of uncertainty.

\section{Results}

\subsection{Simulated and observed fuel load}

A set of nine global simulations was performed with the ecosystem model LPJ-GUESS, varying the combustion factors for woody $\left(c_{\mathrm{w}}\right)$, and for herbaceous fuel $\left(c_{\mathrm{h}}\right)$, the burnedarea input data, and the rate of decomposition of both litter types as described in Sect. 2.1. The simulations are listed in Table 2, together with simulated and observed fuel loads for different biomes. Observations are pre-burn fuel loads from experimental fires or wildfires, simulations the average weighted by burned area over all simulation years, all in tons dry mass per hectare. In those cases where only ranges of observed values are given, we assume the mean to equal the average of the minimum and maximum reported values. For the simulations, the definition of the biomes follows that used by the emission models: grassland with $<20 \%$ LAI fraction of trees, savanna/savanna woodland between 20 and $80 \%$, and forests above that number. Tropical forests are those where the dominant PFT is a tropical tree. The table also shows the assumptions used by Wiedinmyer et al. (2006) and the results of the data-based modelling study by Ito and Penner (2004).

We find that Simulations 3 and 4, representing the assumed range of the wood combustion factor, approximately reproduce the data-based simulations by Ito and Penner (2004) for savannas and forests, but overestimate woody litter in grasslands. Simulated grassland fuel load is also rather sensitive to $c_{\mathrm{W}}$, because there is still considerable tree and shrub derived fuel in this category. This may be explained by the fact that we allowed a relatively high tree fraction in this category. However, all simulations except 9 significantly overestimate 
Table 2. Simulations with LPJ-GUESS, simulated and observed fuel loads in t dry matter/ha.

\begin{tabular}{|c|c|c|c|c|c|c|c|c|}
\hline \multirow{2}{*}{$\begin{array}{l}\text { Simu- } \\
\text { lation }\end{array}$} & \multirow[b]{2}{*}{$c_{\mathrm{w}}^{1}$} & \multirow[b]{2}{*}{$c_{\mathrm{w}}^{2}$} & \multirow{2}{*}{$\begin{array}{c}\text { Burned-area } \\
\text { data }\end{array}$} & \multirow{2}{*}{$\begin{array}{l}\text { Grassland } \\
\text { Total fuel } \\
\end{array}$} & \multicolumn{2}{|c|}{ Savanna/savanna woodland } & \multirow{2}{*}{ Tropical forest } & \multirow{2}{*}{$\begin{array}{l}\text { Extratropical forest } \\
\text { tal fuel }\end{array}$} \\
\hline & & & & & Total fuel & Herbaceous fuel & & \\
\hline 1 & 0 & 1 & GFED $^{3}$ & 11.4 & 58.2 & 4.4 & 80 & 220 \\
\hline 2 & 0.1 & 1 & $"$ & 8.4 & 44.7 & 4.4 & 74 & 210 \\
\hline 3 & 0.2 & 1 & $"$ & 7.1 & 37.5 & 4.4 & 70 & 196 \\
\hline 4 & 0.4 & 1 & $"$ & 5.9 & 29.4 & 4.4 & 64 & 178 \\
\hline 5 & 1 & 1 & ” & 4.8 & 19.8 & 4.4 & 52 & 149 \\
\hline 6 & 0.2 & 1 & $\mathrm{MCD}_{4} 5^{4}$ & 7.1 & 36.6 & 4.4 & 68 & 198 \\
\hline 7 & 0.2 & 1 & $\mathrm{~L}^{3} \mathrm{JRC}^{5}$ & 7.2 & 40.1 & 4.7 & 65 & 166 \\
\hline 8 & 0.2 & 0.9 & GFED $^{3}$ & 7.2 & 37.6 & 4.6 & 70 & 196 \\
\hline $9^{*}$ & 0.3 & 1 & $"$ & 4.8 & 14.3 & 4.4 & 21 & 56 \\
\hline \multicolumn{9}{|c|}{ Observations } \\
\hline \multicolumn{5}{|c|}{ Shea et al. (1996) } & $\begin{array}{c}4.7(n=14) \\
{[1.4]}\end{array}$ & $\begin{array}{c}3.6(n=14) \\
{[1.2]}\end{array}$ & & \\
\hline \multicolumn{5}{|c|}{ Stocks \& Kauffman (1997) } & $\begin{array}{c}5.8(n=56) \\
{[1.6-12.0]}\end{array}$ & & & $\begin{array}{c}60(n=27)^{6} \\
{[41]}\end{array}$ \\
\hline \multicolumn{5}{|c|}{ de Groot et al. (2009) ${ }^{7}$} & & & & $\begin{array}{c}42(n=46) \\
{[21]}\end{array}$ \\
\hline \multicolumn{5}{|c|}{ Govender et al. $(2006)^{8}$} & $\begin{array}{c}5.1(n=1017) \\
{[0.8-14.2]}\end{array}$ & & & \\
\hline \multicolumn{4}{|c|}{ Ito \& Penner (2004) (model) } & 3.7 & 35.4 & & \multicolumn{2}{|r|}{$121^{9}$} \\
\hline \multicolumn{4}{|c|}{ Wiedinmyer et al. (2006) (fixed values) } & 11 & & & 170 & 120 \\
\hline
\end{tabular}

Values in [...] are range or standard deviation. ${ }^{*}$ Woody litter turnover time changed from 20 to 4 yr. ${ }^{1}$ Combustion factor for woody litter. ${ }^{2}$ Combustion factor for herbacous litter. ${ }^{3}$ 9/1996-12/2009. ${ }^{4}$ MODIS 4/2000-12/2009. ${ }^{5}$ 4/2000-3/2007. ${ }^{6}$ Data for Canada. Inferred from fuel load divided by combustion completeness (CC); CC range translated to standard deviation assuming range corresponds to normal distribution between $1 / n$ and $(n-1) / n$ fractiles. ${ }^{7}$ Table 3 , excl. open woodland category. ${ }^{8}$ Table 4 , excl. Shea et al. (1996). ${ }^{9}$ Both forest categories.

total fuel load compared to the field data, even if $100 \%$ combustion is assumed for both litter categories (Simulation 5). By contrast, simulated fuel loads with the exception of tropical forests are lower than those used by Wiedinmyer et al. (2006).

For Simulation 9, where litter decomposition rates were delibrately adjusted to better match field-observed total fuel in extratropical forests, total fuel load in savannas and savanna woodlands is still higher than observed. For all simulations, simulated herbaceous fuel in savannas is lower but still in reasonable agreement with observations. The combustion factor for herbaceous fuel has only a small impact on simulated fuel load when varied within plausible bounds (Simulation 3 vs. 8).

The use of L3JRC burned area leads to considerably lower simulated fuel loads in extratropical forests due to higher burned area (Simulations 3 and 7), more than the effect of doubling the wood combustion factor (Simulations 3 and 4). In savannas, use of L3JRC increases simulated fuel loads due to the lower burned area in the relevant areas (Giglio et al., 2010). Results with the other two burned area products are very similar between each other.

\subsection{Sensitivity to combustion factor and fuel load}

Simulated carbon emissions from wildfires - independent of chemical species, computed before the application of one of the emission models - are highly sensitive to the choice of the combustion factor for woody fuel (Fig. 2). Within the plausible range of $c_{\mathrm{W}}$ between 0.2 and 0.4 , fire emissions increase by approximately $25 \%$ for Africa and $40 \%$ for the remaining part of the globe. We find a non-linear relationship with diminishing returns, which we attribute to the effect of repeated fires. If we assume that all woody fuel not consumed in a single fire year eventually decomposes, we would expect a linear increase between the points with $c_{\mathrm{W}}=0$ and 1 . The simulated amount, however, is considerably higher for intermediate values. The impact of the non-linear response is also more pronounced for Africa (difference of $364 \mathrm{TgC} \mathrm{yr}^{-1}$ or $25 \%$ of emissions against linear response at $c_{w}=0.4$, compared to $224{\mathrm{TgC} \mathrm{yr}^{-1}}^{-1}$ or $18 \%$ for rest-of-world, Fig. 2), which we attribute to the higher fire frequency in Africa.

Similar to fuel loads, simulated emissions are rather insensitive to the choice of the combustion factor for herbaceous fuel (Fig. 2, red symbols). Simulation 9, with faster turnover time for woody litter better matching observed fuel loads, results in CO emissions about one third lower than the standard case, or GFED3. Note that the standard case has $c_{\mathrm{W}}=0.2$, 


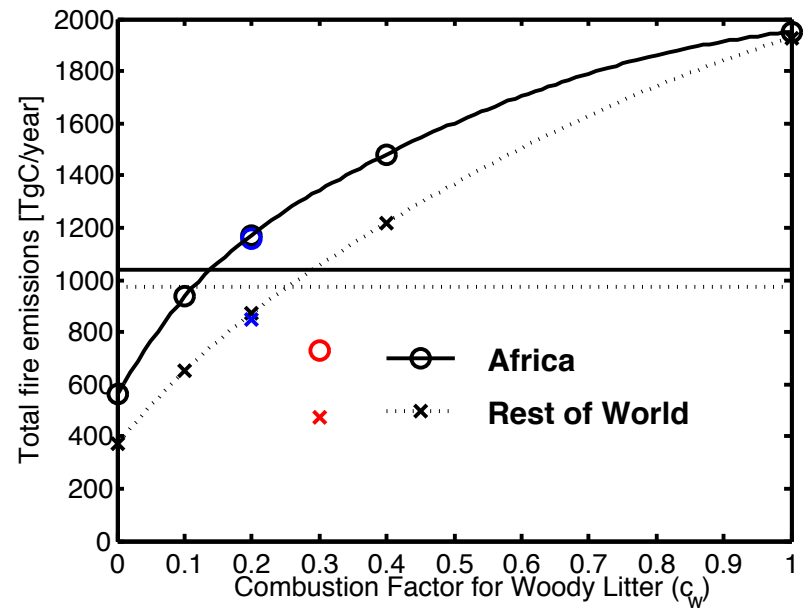

Fig. 2. Sensitivity of average global fire emissions 1997-2009. The horizontal lines show GFED3 emissions during the same period. Blue symbols: combustion efficiency for herbaceous fuel reduced from 1 to 0.9 . Red symbols: litter turnover adjusted to match observed fuel loads.

but the one with faster woody litter turnover $c_{\mathrm{W}}=0.3$. The contribution of herbaceous fuel can be inferred from emissions at the point $c_{w}=0$ : those emissions contribute about half (at $c_{w}=0.2$ ) to one third ( $c_{w}=0.4$ ) to the global total.

We also find that the value of $c_{\mathrm{w}}=0.2$ (Simulation 3 of Table 2) with GFED3 burned area gives results that are closest to the emission estimates of GFED3 (Fig. 2). This value of 0.2 is retained throughout the remainder of this text and for further sensitivity analyses, where dependence of emissions of chemical species on burned area observations or emission model are considered.

Another way of assessing the impact of different combustion factors and fuel loads is to compare the simulated emissions with GFED3 burned area and EM1 with those computed by van der Werf et al. (2010), who used the same burned-area data and emission model. While LPJ-GUESS simulates the vegetation present at each site as natural vegetation, the CASA model as used by van der Werf et al. (2010) uses observed vegetation distribution as an external input to the model. CASA also includes peat fires, deforestation and agricultural waste burning explicitly, while LPJ-GUESS simulates all observed fires as wildfires with no live biomass burned. In the case of deforestation fires, this leads to an underestimate of emissions because felling and burning of trees is not simulated. Table 3 shows the LPJ-GUESS and GFED3 $\mathrm{CO}$ emissions for wildfires and agricultural burning, as well as total emissions for GFED3. For a definition of the regions see (Giglio et al., 2010) and Fig. A2.

Global emissions are $33 \%$ higher for LPJ-GUESS compared to GFED3, about equal for Northern Hemisphere Africa, and $30 \%$ higher for Southern Hemisphere Africa. Boreal North America is also higher by $43 \%$, while Boreal Asia is in close agreement. Southeast and Equatorial Asia are again somewhat higher for LPJ-GUESS when only considering wildfires and agricultural burning, but here the GFED3 total emissions are much higher due to the contribution from peat fires. The region that stands out in this comparison is Central Asia, where LPJ-GUESS emissions are an order of magnitude higher than GFED3. As Fig. 3 reveals, the region (cf. Fig. A2) has high simulated CO emissions especially in regions known to be dominated by agricultural fields (Ramankutty and Foley, 1999). One explanation for the discrepancy in emissions is that LPJ-GUESS simulates only potential natural vegetation, leading to overestimated fuel loads. This also explains why Europe and Temperate North America have much higher simulated emissions for LPJ-GUESS. There is, however, reasonable agreement for the major emission regions, such as Africa, Australia, and South America.

\subsection{Sensitivity to burned area}

With a much different burned area detection algorithm than GFED3 or MODIS MCD45 (Roy and Boschetti, 2009), the L3JRC product (Tansey et al., 2008) leads to much higher emissions in the mid to high latitudes (Boreal and Temperate North America, Europe, Boreal and Central Asia; Table 3). The differences are by order of magnitude of emissions, as opposed to the much smaller differences between the two MODIS or predominantly MODIS-based products. For Africa, however, L3JRC emissions are somewhat lower than MODIS or GFED3 emissions, which corresponds to lower burned area in the region (Roy and Boschetti, 2009). MODIS and GFED3, on the other hand, are again very similar for this region.

A comparison shown in Fig. 4 reveals not only large differences in magnitude but also in interannual variability between simulations with different burned area data. For example, for Africa (Fig. 4a), interannual variability is much larger for MODIS (standard deviation 2001-2009: 13.1 Tg) than for GFED3 burned area $(8.3 \mathrm{Tg})$. For L3JRC, even temporal maxima and minima change sign compared to the other products: note for example that 2005 for Africa is a minimum for L3JRC, and a maximum for the other products, or 2002 in the boreal zone, which is a pronounced temporal minimum in L3JRC, but not for any of the other data sets (Fig. 4a, b). On a global scale (Fig. 4c), GFED3 and MODIS lead to very similar results, however, with L3JRC standing out as much higher. The difference between GFED3 emissions and emissions from LPJ-GUESS with GFED3 burned area for 1997 can be attributed again to peat fires, which were especially wide-spread during the 1997/1998 El Niño (Page et al., 2002; Langenfelds et al., 2002).

Not surprisingly, the spatial patterns of simulated wildfire emissions are dominated by the spatial patterns of the burned area product used. As GFED3 is mainly based on MODIS data from early 2000 onwards, those spatial patterns fall into two groups, with MODIS MCD45 and GFED3 as one, and L3JRC as the other (see Fig. 4 for the example of CO). A 


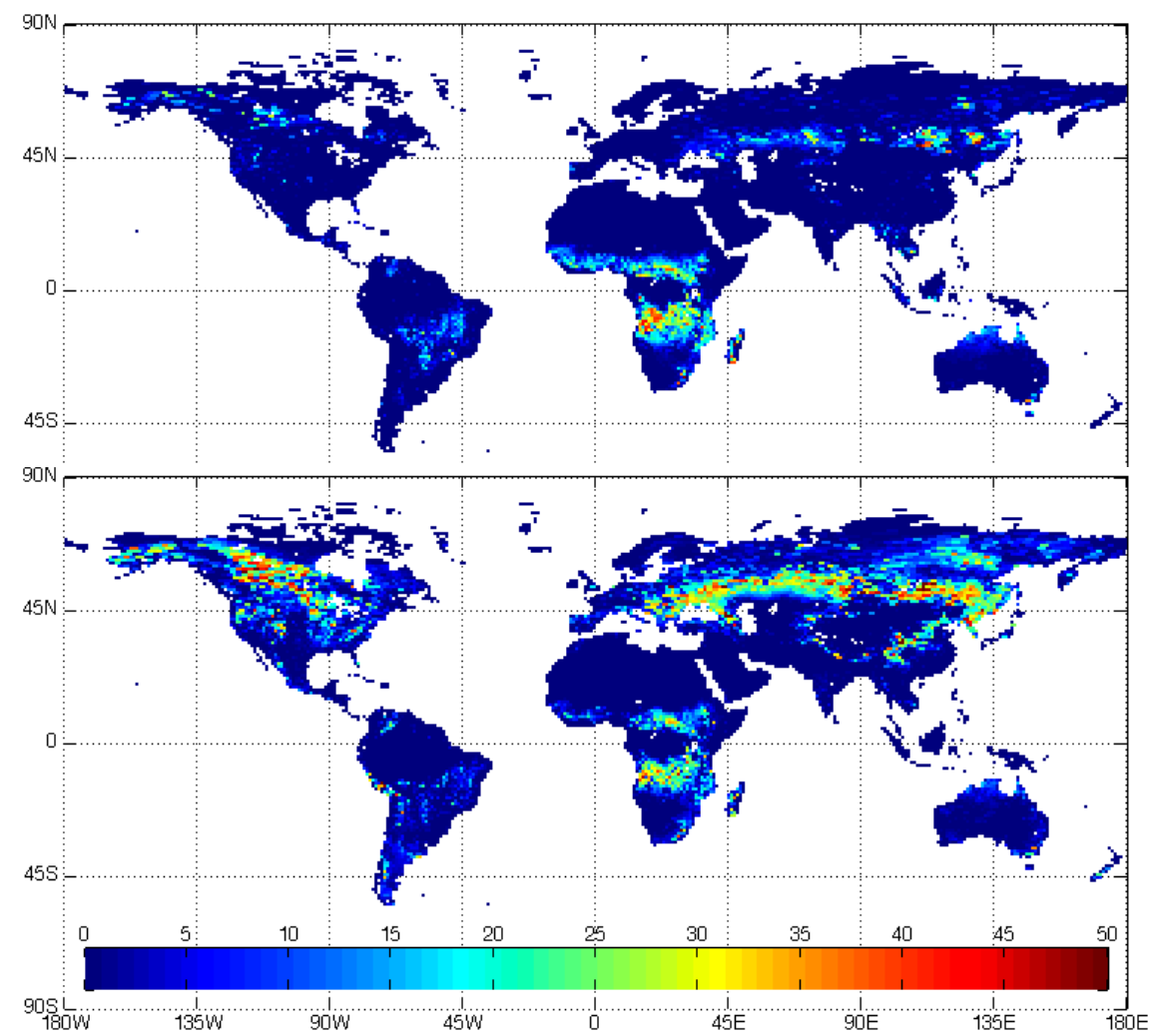

Fig. 3. $\mathrm{CO}$ emissions in $\mathrm{gC} \mathrm{m}^{-2} \mathrm{yr}^{-1}$ for $c_{\mathrm{W}}=0.2$ and Emission Model 1, average 2001-2006. Upper panel: GFED3 burned area. Lower panel: L3JRC burned area.

regional breakdown of the emissions (Table 3) also shows great similarity between GFED and MODIS, with the exception of some areas with minor contributions: Equatorial Asia, notably Boreal North America, where MODIS is close to half of GFED3, and Europe and Southeast Asia where this difference is reversed. The different burned area for Equatorial Asia was already noted by Giglio et al. (2010), where GFED3 reports generally much higher values. This was attributed to a mapping algorithm more resistant to cloud and aerosol contamination, leaving fewer undetected burned pixels.

\subsection{Emission models}

Simulated emissions are found to be rather sensitive to the choice of emission model, as is shown in Fig. 5. Annual carbon emissions for EM1 are $6655 \mathrm{Tg} \mathrm{CO}_{2}(92.9 \%$ of carbon emissions), $315 \mathrm{Tg} \mathrm{CO}(6.8 \%), 14 \mathrm{Tg}$ methane $(0.5 \%)$ and $18 \mathrm{Tg}$ non-methane hydrocarbons $(0.6 \%)$, whereas for EM2 the figures are $8886 \mathrm{Tg} \mathrm{CO}_{2}(90.4 \%), 415 \mathrm{Tg} \mathrm{CO}(8.6 \%)$, $15 \mathrm{Tg}$ methane $(0.6 \%)$, and $15 \mathrm{Tg}$ NMHCs $(0.4 \%)$. The calculation assumes an average molar mass per carbon atom of $20 \mathrm{~g}$ for NMHCs derived from the data by P. Merlet (personal communication, 2008) for tropical grasslands and savannas. EM2 thus predicts a considerably lower combustion efficiency for wildfires with much higher $\mathrm{CO}$ emissions, while
EM1 yields a smaller combustion efficiency, but with fires producing considerably more NMHCs relative to methane.

In general, the choice of emission model impacts more the magnitude and less the geographical breakdown of emissions (Fig. 5). At least for $\mathrm{CO}$ and methane, the share of emissions going to Africa is somewhat higher for EM2 (CO: $56 \%$, methane: $55 \%$ ) than for EM1 (CO: $52 \%$, methane: $51 \%$ ). For aerosols $\left(\mathrm{PM}_{2.5}\right)$, there are also some notable redistributions in emissions: For EM4, most emissions come from Africa $(60 \%)$ and Southeast Asia and Oceania (11\%), with the boreal and temperate zones only contributing $10 \%$ each. EM1, at the other end of the spectrum, allocates only $47 \%$ to Africa, but $18 \%$ each to the boreal and temperate zones, and only $8 \%$ to Southeast Asia and Oceania. We further find that choice of emission model generally has only a small effect on interannual variations of emissions (results not shown).

\subsection{Contributions to emission uncertainties}

We compare our best-guess estimate of global chemical emissions, for which we use EM1, $c_{\mathrm{W}}=0.2$ and GFED3 burned area, with uncertainty ranges resulting from uncertainties in emission factor, emission model, fuel combustion, simulated fuel load, or burned area (Table 4; see Sect. 2.4). Since this is only a first attempt to characterize uncertainty ranges of chemical emissions from wildfires, we do not 
(a)

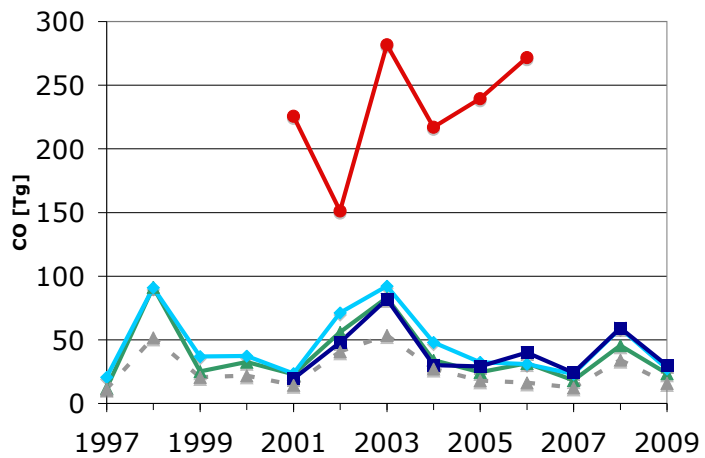

(b)

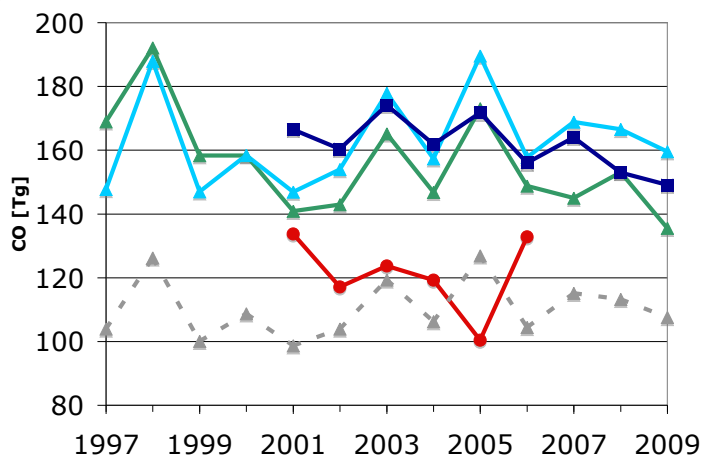

(c)

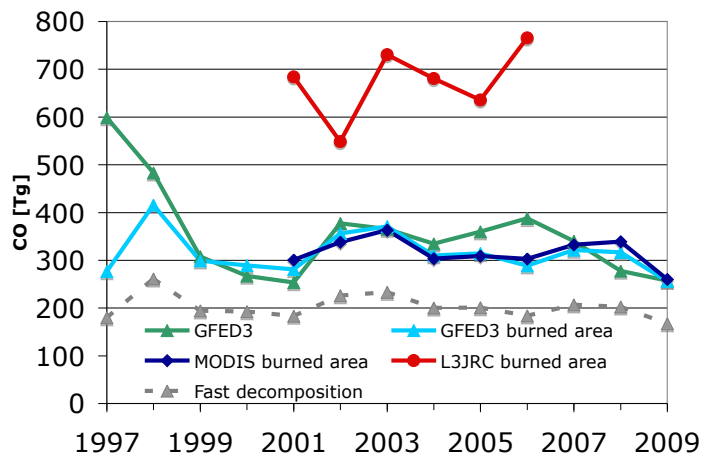

Fig. 4. Annual $\mathrm{CO}$ emissions in $\mathrm{Tg}$ for $c_{\mathrm{W}}=0.2$ and Emission Model 1, for different burned area data sets and for fast litter decomposition, as well as GFED3 emissions. (a) Boreal Asia and North America. (b) Africa. (c) Globe.

include an estimate of overall uncertainty, nor do we base our best guess on the average across emission models and burned area products.

Considering only orders of magnitude, we find that the different factors contribute about equal levels of uncertainty to the simulated emissions. Only for $\mathrm{CO}_{2}$, the emission model has a minor effect on uncertainties. Notable is a rather high contribution from simulated fuel loads.

There are cases, however, where emission factor uncertainty has a similar or larger impact on emissions than any of the other factors. The simulated emissions of propane, $\mathrm{SO}_{2}$, xylenes, ethanol and acetaldehyde depend more strongly on uncertainties in emission model than on fuel load and combustion. Propane has a much higher emission factor for tropical forest $\left(1.04 \mathrm{~kg} \mathrm{~g}^{-1}\right.$ dry matter, P. Merlet, personal communication, 2008) than for savanna and grassland (0.086) or extratropical forest $(0.27)$, but this high factor for tropical forests is based on only two measurements. Xylenes have the highest estimated emission factor for extratropical forest (0.2) based on only one measurement (vs. 0.043 and 0.087 for the other biomes), and ethanol has only one measurement for extratropical forest and none for the other ecosystems. For acetaldehyde, the situation is similar to propane, with only two measurements from tropical forests, but a more than four times higher emission factor than for savannas and grasslands. Other cases with relatively large uncertainties due to emission factors are $\mathrm{NO}_{\mathrm{x}}, \mathrm{NH}_{3}$, ethene, propene, benzene, toluene, methanol, formaldehyde, and acteone.

We find a remarkably large difference between the two emission models for $\mathrm{CO}$, resulting in a range of $100 \mathrm{Tg} \mathrm{yr}^{-1}$, twice as much as the effect of the uncertainty of the emission factor of EM1. We combine both emission factor and emission model uncertainty and assume they are uncorrelated to derive the overall influence on uncertainties through the choice of emission model. We thus arrive at the following indicative esimates for the five main groups of emitted species $\left(\mathrm{CO}_{2}, \mathrm{CO}, \mathrm{CH}_{4}, \mathrm{NHMCs}\right.$ and particulate matter): about $50 \%$ estimated uncertainty from fuel load, 30 to $40 \%$ from fuel combustion, $25 \%$ from burned area, and 20 to $30 \%$ from emissions modelling. Exceptions are $\mathrm{CO}_{2}$, with $5 \%$, and $\mathrm{CO}$ with $36 \%$ uncertainty from emission modelling.

\section{Discussion}

Even though some of the results have been presented in terms of uncertainties, it must be stressed that the reported ranges are only first estimates. These estimates have been derived from what is essentially a sensitivity analysis of chemical emissions from wildfires to plausible scenarios of parameter, model or input data choice. The first issue to discuss is therefore how the models used here compare with other global modelling efforts of wildfire emissions.

We find that the standard simulation agrees reasonably well with emissions by GFED3, while at the same time appears to overestimate fuel loads compared to field data. Other models, however, have used or re-produced similar or higher fuel loads. Combustion factors are similar to other studies or to observations, as shown in Sect. 2.1. Choice of the combustion factor for herbaceous fuel has generally little impact on overall emissions, because it is rather well constrained by the data. However, reducing simulated fuel loads to agree more closely with observations (Simulation 9) results in strongly reduced emissions. Van der Werf et al. (2010) report that regional atmospheric inversion studies for Africa as well as Alaska and Canada indicate rather good agreement with 
Table 3. Average annual CO emissions in Tg 2001-2006 with LPJ-GUESS and Emission Model 1 using different remotely sensed burned area products: GFED3 (Giglio et al., 2010), L3JRC (Tansey et al., 2008), and MODIS MCD45 (Roy et al., 2005). Last 2 columns show emissions by GFED3. Wildfires (Wildf.) exclude deforestation, peat fires and agricultural waste burning (Agric.).

\begin{tabular}{lrrrrr}
\hline Model & \multicolumn{2}{c}{ LPJ-GUESS + EM1 } & \multicolumn{2}{c}{ GFED3* } \\
\hline Burned area product & GFED3 & MODIS & L3JRC & GFED3 \\
\hline Types of fires & \multicolumn{2}{c}{ Wildfires + Agric. Fires } & Wildf.+Agric. & All \\
\hline Boreal North America & 20.2 & 12.8 & 93.1 & 14.1 & 14.2 \\
Temperate North America & 4.2 & 5.9 & 53.1 & 1.5 & 1.5 \\
Central America & 1.6 & 1.7 & 4.6 & 1.8 & 3.3 \\
Northern Hemisph. South America & 2.8 & 2.4 & 3.6 & 1.9 & 3.5 \\
Southern Hemisph. South America & 26.5 & 24.0 & 37.1 & 17.9 & 48.7 \\
Europe & 1.5 & 3.5 & 26.9 & 0.8 & 0.8 \\
Middle East & 0.9 & 1.3 & 6.6 & 0.4 & 0.3 \\
Northern Hemisphere Africa & 60.5 & 62.2 & 41.5 & 60.0 & 67.8 \\
Southern Hemisphere Africa & 103.4 & 102.9 & 79.7 & 79.6 & 85.1 \\
Boreal Asia & 29.4 & 28.5 & 137.9 & 27.8 & 26.8 \\
Central Asia & 42.8 & 51.1 & 167.2 & 5.9 & 6.2 \\
Southeast Asia & 5.9 & 8.4 & 6.9 & 6.0 & 16.6 \\
Equatorial Asia & 1.8 & 0.4 & 0.2 & 1.8 & 50.1 \\
Australia and New Zeeland & 18.4 & 14.1 & 15.8 & 19.9 & 20.5 \\
Global & 319.9 & 319.3 & 674.0 & 239.2 & 346.3 \\
\hline
\end{tabular}

* van der Werf et al. (2010).

GFED3. Based on those comparisons, we would expect the emissions of Simulation 9 to be too low.

There might be a number of factors contributing to this apparent contradiction. Firstly, fuel loads in savannas strongly depend on mean annual rainfall (Govender et al., 2006), and the precipitation data used by LPJ-GUESS has to rely on a rather sparse network of stations in most of those areas (Mitchell and Jones, 2005). Also, the LAI fraction of trees and shrubs assumed in this study for the savanna/savanna woodland category ( 20 to $80 \%$ ) is somewhat higher then that assumed for example by the International Geosphere Biosphere Program (10 to $60 \%$, Friedl et al., 2002). Simulated total fuel in LPJ-GUESS is similar to other modelling studies, but should be thought of as representing not only surface fuels, but also fuels in killed shrubs or short trees, for example, that contribute to emissions but are not captured by the field data cited. It could also represent collected fuel wood (van der Werf et al., 2010), which was estimated to amount to $10 \%$ of savanna emissions in Africa (Williams et al., 2007). Fuel wood likewise contributes to emissions but does not appear in fuel load data for African savannas. Possibly, LPJGUESS effectively accounts for these effects by assuming a higher woody fuel load than is in fact found on the ground.

Another explanation, which has been discussed before, states that part of what is simulated as fuel in LPJ-GUESS is wood contained in dead standing trees that do not burn or contribute to emissions. If we assume half of the modelled woody fuel is indead standing trees and halve the combustion factor for woody fuel from the plausible range of 0.2 to
0.4 to values between 0.1 and 0.2 , we obtain the following results (Simulations 2 and 3, see Table 2): simulated woody fuel in savannas is between 33 and $40 \mathrm{t} / \mathrm{ha}$, and surface litter between 16 and $20 \mathrm{t} / \mathrm{ha}$. Simulation 3, resulting in $16 \mathrm{t} / \mathrm{ha}$, also has similar emissions to GFED3. While this is still too high compared to observations, a combination of both proposed factors, a systematic difference in the tree fraction between simulations and observations, and possible biases between actual and observed rainfall might be able to explain the difference.

For the sensitivity to emission factors we used ranges defined by one standard deviation reported by P. Merlet (personal communication, 2008). Whether these ranges represent the plausible range of emission factors can be addressed by comparing results with different emission models against the propagation of uncertainties in emission factors. We find that propagation of uncertainties might somewhat underestimate the impact of varying emission factors within a full plausible range, in one case (CO) even substantially. However, we need to bear in mind that the model of MCE used in EM2 was derived from data from African savannas only and might be less applicable in e.g. boreal forests. We therefore assume that the sensitivity of emissions to emission models can be reasonably approximated by varying the emission factor within the reported one standard deviation of the mean. However, we must also note that using a more process based model of emission factors, as presented by van Leeuwen and van der Werf (2011), it might become possible to model emission factors more accurately, if it turns 
Table 4. Global wildfire emissions in $\mathrm{Tg} \mathrm{yr}^{-1}$ with Emission Model $1, c_{\mathrm{W}}=0.2$ and GFED3 burned area (best guess), and uncertainties from various factors. "Higher alkenes" and "higher alkanes" with a least $4 \mathrm{C}$ atoms. OC: organic carbon. BC: black carbon. NMHCs: non-methane hydrocarbons. TPM: total particulate matter. $\mathrm{PM}_{2.5}$ particulate matter up to 2.5 micron.

\begin{tabular}{|c|c|c|c|c|c|c|}
\hline \multirow[b]{2}{*}{ Species } & \multirow[b]{2}{*}{ Best guess 1} & \multicolumn{4}{|c|}{ Uncertainty resulting from: } & \multirow[b]{2}{*}{ 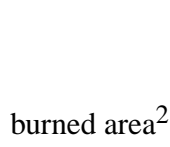 } \\
\hline & & emission factor ${ }^{1}$ & emission model ${ }^{1}$ & fuel combustion ${ }^{1}$ & fuel load ${ }^{1}$ & \\
\hline $\mathrm{CO}_{2}$ & 6656 & 271 & 230 & 2123 & 3273 & 1681 \\
\hline $\mathrm{CO}$ & 315 & 50 & 100 & 112 & 169 & 79 \\
\hline $\mathrm{CH}_{4}$ & 14.4 & 2.8 & 0.9 & 5.6 & 8.2 & 3.2 \\
\hline NMHCs & 18.5 & 4.9 & 3.5 & 6.7 & 10.0 & 4.3 \\
\hline TPM & 44.2 & 10.2 & - & 15.8 & 23.7 & 12.1 \\
\hline $\mathrm{PM}_{2.5}$ & 29.3 & 6.8 & 3.7 & 11.0 & 16.3 & 8.0 \\
\hline $\mathrm{NO}_{\mathrm{x}}$ & 9.75 & 3.45 & - & 3.30 & 5.03 & 2.65 \\
\hline $\mathrm{N}_{2} \mathrm{O}$ & 0.89 & 0.30 & - & 0.29 & 0.44 & 0.23 \\
\hline $\mathrm{NH}_{3}$ & 3.85 & 1.77 & - & 1.37 & 2.07 & 1.08 \\
\hline $\mathrm{SO}_{2}$ & 2.26 & 3.09 & - & 0.85 & 1.26 & 0.61 \\
\hline $\mathrm{OC}^{2}$ & 18.4 & 4.1 & - & 6.8 & 10.2 & 5.5 \\
\hline $\mathrm{BC}$ & 2.04 & 0.52 & - & 0.68 & 1.04 & 0.52 \\
\hline ethene & 4.20 & 1.43 & - & 1.48 & 2.23 & 0.99 \\
\hline ethane & 2.24 & 0.65 & - & 0.89 & 1.30 & 0.47 \\
\hline propene & 2.20 & 0.78 & - & 0.85 & 1.25 & 0.43 \\
\hline propane & 1.25 & 2.82 & - & 0.56 & 0.79 & 0.16 \\
\hline higher alkenes & 2.01 & 0.45 & - & 0.71 & 1.07 & 0.50 \\
\hline higher alkanes & 0.78 & 0.19 & - & 0.29 & 0.44 & 0.22 \\
\hline benzene & 1.40 & 0.57 & - & 0.49 & 0.75 & 0.38 \\
\hline toluene & 0.95 & 0.46 & - & 0.34 & 0.51 & 0.26 \\
\hline xylenes & 0.33 & 0.31 & - & 0.13 & 0.19 & 0.10 \\
\hline methanol & 7.50 & 3.66 & - & 2.68 & 4.00 & 1.67 \\
\hline ethanol & 0.05 & 0.06 & - & 0.02 & 0.03 & 0.01 \\
\hline formaldehyde & 5.18 & 2.12 & - & 2.06 & 3.02 & 1.25 \\
\hline acetaldehyde & 3.80 & 2.55 & - & 1.54 & 2.23 & 0.69 \\
\hline acetone & 2.22 & 0.79 & - & 0.76 & 1.15 & 0.56 \\
\hline
\end{tabular}

${ }^{1}$ 1997-2009. ${ }^{2}$ 2001-2006. Range based on two samples shown in italics.

out that other factors than fuel composition or biome are better predictors.

The remaining question is whether the rather wide range of burned-area estimates used in this study (L3JRC was excluded for the boreal zone) can be considered a plausible uncertainty estimate. Had we used only L3JRC and MCD45, the burned-area based uncertainty of $\mathrm{CO}_{2}$ emission would have dropped from 1680 to $240 \mathrm{TgC}^{-1}$. However, both these data sets are mainly based on data from the same satellite sensor, so that the regional differences between the two cannot be expected to be a good estimator of uncertainties. For example, Chang and Song (2009) showed that MCD45 underestimates monthly burned area by $44 \%$ for Canada, $53 \%$ for the United States (US), and $27 \%$ for China against regional estimates. On the other hand, L3JRC overestimates by factors of 1.5 and 4 for US and China, respectively (for Canada and Alaska, L3JRC does not enter the uncertainty calculation). For Africa, however, L3JRC underestimates burned area compared to analyses of high-resolution images (Roy and Boschetti, 2009). We therefore assume that the uncertainty estimate for the impact of burned area is reasonable, even if somewhat high.

A new finding is that there is not only a large bias between L3JRC and the other two satellite products, but that interannual variability simulated using L3JRC differs significantly from using the predominantly MODIS-based products. Therefore, further validation of satellite burned area also needs to consider how reliably interannual variations are reproduced.

This study shows a high sensitivity of emissions to uncertainties in burned area data, which is relevant in the context of climate change and the need for projections of chemical emissions from wildfires. As far as modelling burned area is concerned, the results from global fire models are promising, but their application remains a substantial challenge. For example, Thonicke et al. (2010) report fractional area burned in southern Europe and Turkey similar to African savannas. However, in GFED3 only central Portugal 


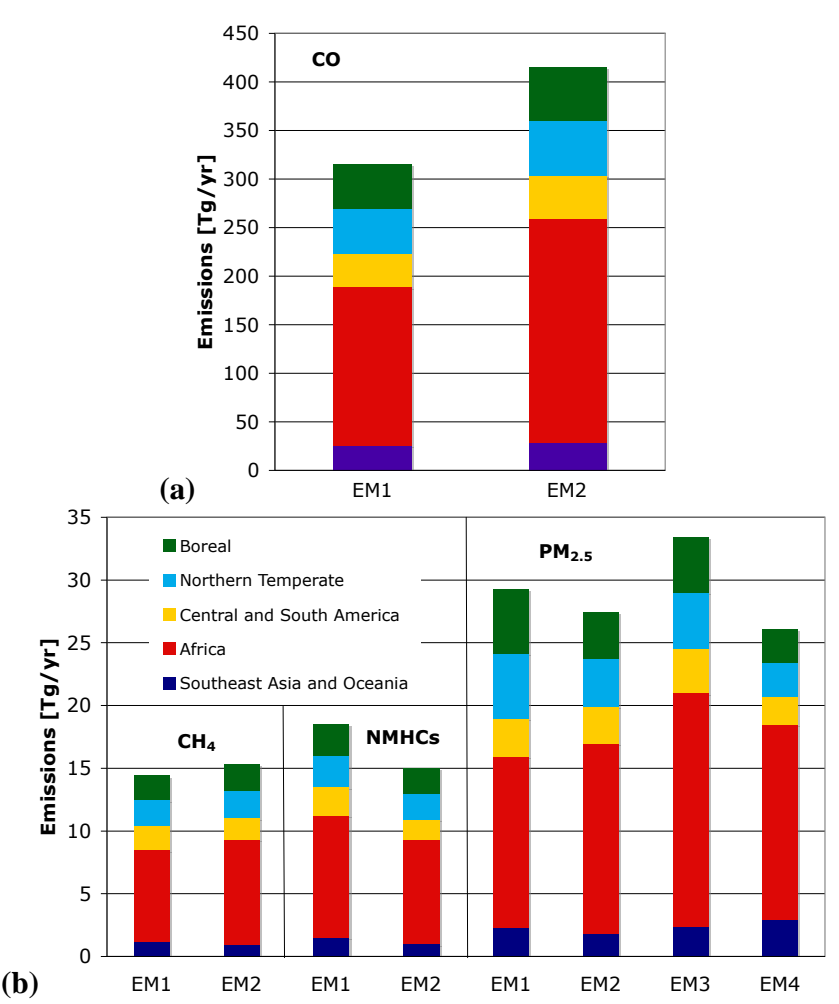

Fig. 5. Average emissions 1997-2009 region of (a) CO; and of (b) methane, non-methane hydrocarbons (NMHCs) and aerosol particulate matter up to 2.5 microns. Emissions are for $c_{\mathrm{W}}=0.2$ and different emission model (EM). Boreal: Boreal North America and Boreal Asia. Northern Temperate: Temperate North America, Europe, Middle East and Central Asia. Southeast Asia and Oceania: Southeast Asia, Equatorial Asia and Australia and New Zealand.

has areas with values between 5 and $10 \% \mathrm{yr}^{-1}$, with the rest of the region closer to $1 \% \mathrm{yr}^{-1}$. By comparison, African savannas burn between 10 and $30 \%$ of their area each year. While the model by Thonicke et al. (2010) is more process based, Kloster et al. (2010) show results of simulated burned area using the much simpler approaches of Thonicke et al. (2001) and Arora and Boer (2005) and find reasonable broad agreement with L3JRC and GFED2 (Giglio et al., 2006). However, Giglio et al. (2010) found that GFED3 agrees substantially better with independent data than either GFED2 or L3JRC. This has consequences for model evaluation: for example, the model by Arora and Boer (2005) simulates twice to 6 times the GFED2 burned area for Europe, but GFED3 has $75 \%$ less burned area in the same region than GFED2 (Giglio et al., 2010). Because no modelpredicted burned area can be expected to have lower uncertainty than the best observations - as they rely on observational evidence for their design - we believe that further validation and improvement of remotely sensed products is necessary for improved prediction of burned area and fire emissions. Apart from that, we need further efforts for designing, parameterising and refining predictive fire models that can be tested against burned-area observations at various spatial scales (Lehsten et al. 2010).

Overall, we find that in order to arrive at a predictive capability for the impacts of climate change on wildfire emissions, the main priority is to obtain more data on combustion factors and in particular factors that characterize the associated weather and fuel moisture conditions, as the currently available data seriously limit modelling capability (Ito and Penner, 2004; Wiedinmyer et al., 2010). This includes improved precipitation data as the main driver for fuel load (Govender et al. 2006). The next highest priority would be a systematic comparison of global and regional data on burned area, and a systematic improvement of burned-area models to better match well-validated observations. Finally, the range of emissions reported here could not only be tested against atmospheric inversions of relatively long-lived chemical tracers such as CO (Kopacz et al., 2010), but ultimately parameters of the emission model could be constrained directly via inverse modellling, similar to the technique used in Carbon Cycle Data Assimilation (Rayner et al., 2005).

\section{Conclusions}

We have presented a framework for exploring the sensitivity of global chemical emissions from wildfires to various uncertain model inputs and parameterisations. Simulated fuel loads were comparable to other modelling studies, but higher than observed for African savannas. We have dicusssed several factors that could explain the difference. We concluded that modelled fuel loads still contribute to a large uncertainty in the estimated wildfire emissions.

The study futher highlights the need for models of combustion completeness as a function of climatic conditions, possibly in conjunction with reliable models of fire intensity, and the need for better models of emission factors for several species. For the main emitting species, however, the main issue is accurate modelling of burned area and combusted biomass, crucial for assessing fire emissions in past or future environments.

Our results can be used by the atmospheric modelling community to consider a range of emission scenarios rather than a fixed one, reflecting the uncertainty range due to current modelling capabilities. Modelling different emission scenarios together with chemical transport can be used to further constrain emissions, given suitable observations and long-lived tracers.

We conclude that model-based prediction of chemical emissions from wildfire, either for present or future conditions, still carries a high degree of uncertainty.

All emission fields presented are available on request by the corresponding author. 


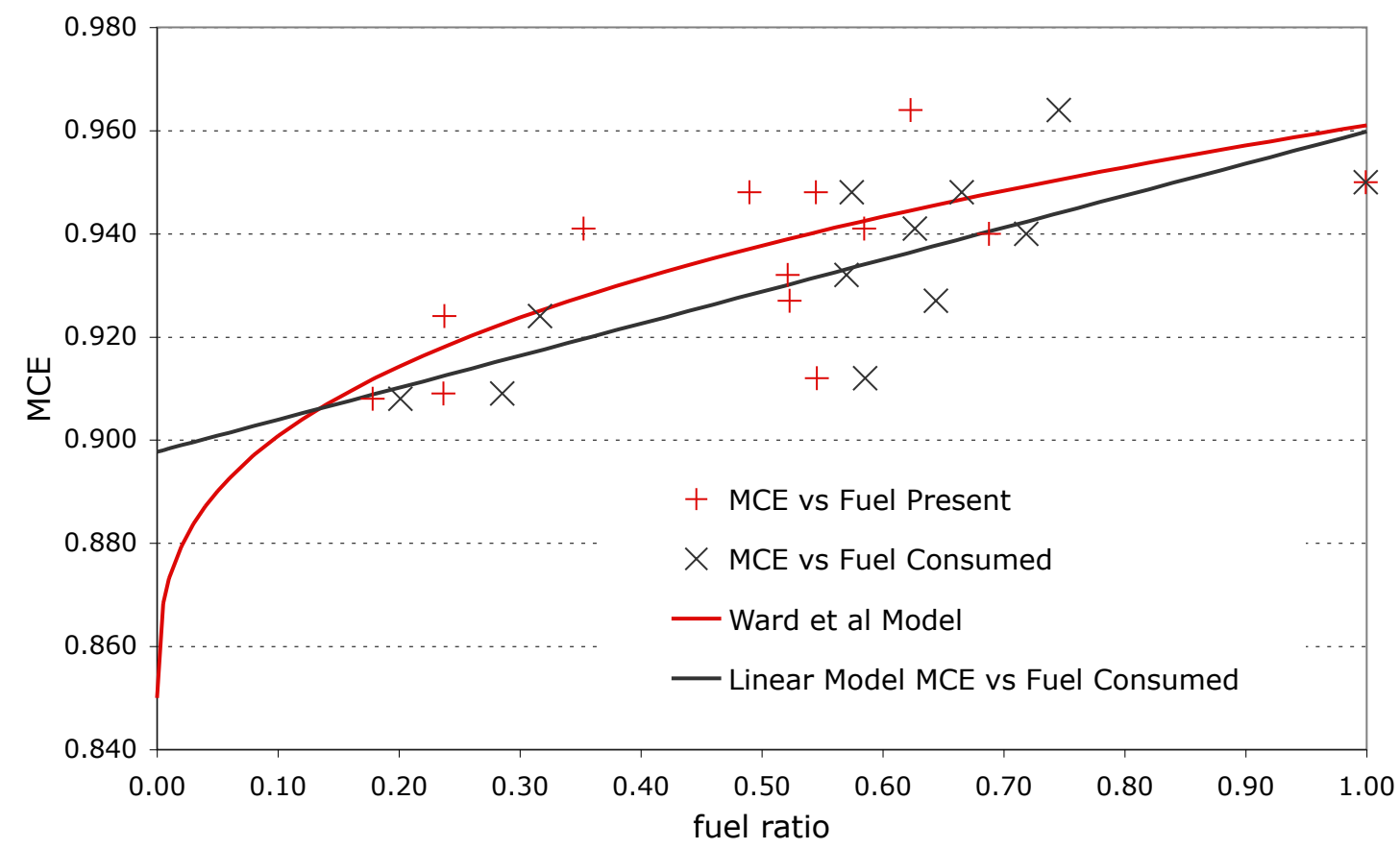

Fig. A1. Models of Modified Combustion Efficiency (MCE) against fuel ratio according to Ward et al. (1996) and derived as in the main text, as well as measured MCE by Ward et al. (1996) versus fuel ratio for either fuel present before the fire, or fuel consumed during the fire. The Ward et al model is a function of the fuel ratio of the fuel present, the linear MCE model derived here a function of the fuel ratio of the fuel consumed. The fuel ratio is defined as the amount of grass fuel (live grass and grass litter) divided by total fuel amount (including non-grass debris).

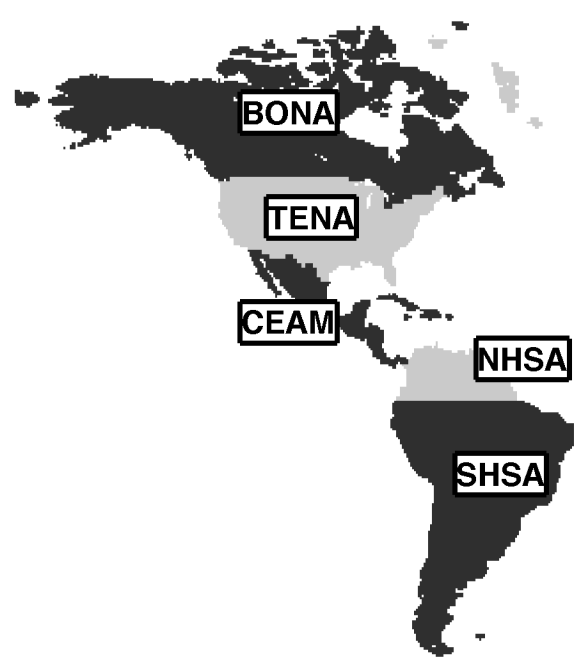

BONA Boreal North America

TENA Temperate North America

CEAM Central America

NHSA Northern Hemisphere South Americe

SHSA Southern Hemisphere South America

EURO Europe

MIDE Middle East

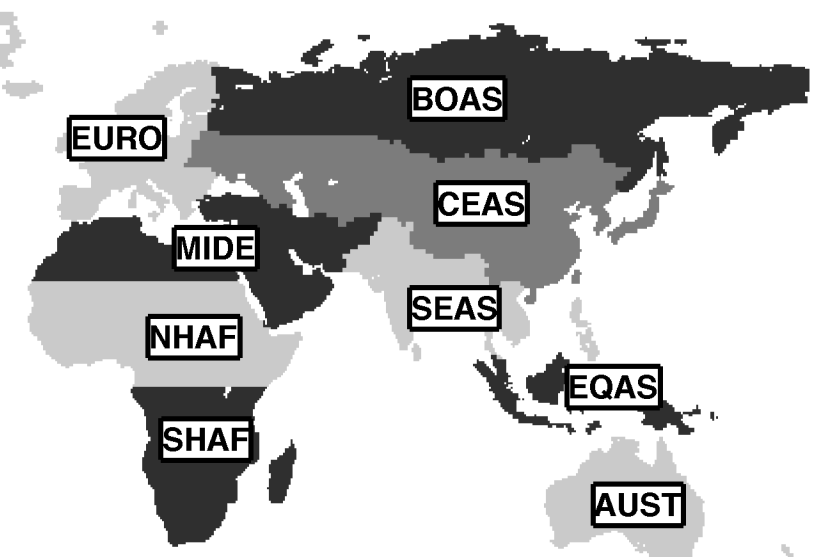

NHAF Northern Hemisphere Africa

SHAF Southern Hemisphere Africa

BOAS Boreal Asia

CEAS Central Asia

SEAS Southeast Asia

EQAS Equatorial Asia

AUST Australia and New Zealand

Fig. A2. GFED regions as used in this study (from Giglio et al., 2010). 
Acknowledgements. This work was supported by EU contracts 265148 (Pan-European Gas-Aerosol-climate interation Study, PEGASOS), and 243888 (Forest fires under climate, social and economic changes in Europe, the Mediterranean and other fireaffected areas of the world, FUME). The authors would like to thank Claire Granier for suggestions on which chemical species to include, and two anonymous reviewers for their critical comments, which we believe have helped to greatly improve the manuscript.

Edited by: K. Carslaw

\section{References}

Andreae, M. O. and Merlet, P.: Emission of trace gases and aerosols from biomass burning, Global Biogeochem. Cy., 15, 955-966, 2001.

Arneth, A., Harrison, S. P., Zaehle, S., Tsigaridis, K., Menon, S., Bartlein, P. J., Feichter, J., Korhola, A., Kulmala, M., O’Donnell, D., Schurgers, G., Sorvari, S., and Vesala, T.: Terrestrial biogeochemical feedbacks in the climate system, Nat. Geosci., 3, 525532, doi:10.1038/Ngeo905, 2010.

Arora, V. K. and Boer, G. J.: Fire as an interactive component of dynamic vegetation models, J. Geophys. Res., 110, G02008, doi:10.1029/2005jg000042, 2005.

Boschetti, L. and Roy, D. P.: Strategies for the fusion of satellite fire radiative power with burned area data for fire radiative energy derivation, J. Geophys. Res., 114, D20302, doi:10.1029/2008jd011645, 2009.

Bowman, D. M. J. S., Balch, J. K., Artaxo, P., Bond, W. J., Carlson, J. M., Cochrane, M. A., D’Antonio, C. M., DeFries, R. S., Doyle, J. C., Harrison, S. P., Johnston, F. H., Keeley, J. E., Krawchuk, M. A., Kull, C. A., Marston, J. B., Moritz, M. A., Prentice, I. C., Roos, C. I., Scott, A. C., Swetnam, T. W., van der Werf, G. R., and Pyne, S. J.: Fire in the Earth System, Science, 324, 481-484, doi:10.1126/Science.1163886, 2009.

Chang, D. and Song, Y.: Comparison of L3JRC and MODIS global burned area products from 2000 to 2007, J. Geophys. ResAtmos., 114, D16106, doi:10.1029/2008jd011361, 2009.

de Groot, W. J., Pritchard, J. M., and Lynham, T. J.: Forest floor fuel consumption and carbon emissions in Canadian boreal forest fires, Can. J. Forest. Res., 39, 367-382, doi:10.1139/X08-19, 2009.

Duncan, B. N., Martin, R. V., Staudt, A. C., Yevich, R., and Logan, J. A.: Interannual and seasonal variability of biomass burning emissions constrained by satellite observations, J. Geophys. Res., 108, 4100, doi:10.1029/2002jd002378, 2003.

Ellicott, E., Vermote, E., Giglio, L., and Roberts, G.: Estimating biomass consumed from fire using MODIS FRE, Geophys. Res. Let., 36, L13401, doi:10.1029/2009g1038581, 2009.

Etheridge, D. M., Steele, L. P., Langenfelds, R., and Francey, R. J.: Natural and anthropogenic changes in atmospheric $\mathrm{CO}_{2}$ over the last 1000 years from air in Antarctic ice and firn, J. Geophys. Res., 101, 4115-4128, 1996.

Friedl, M. A., McIver, D. K., Hodges, J. C. F., Zhang, X. Y., Muchoney, D., Strahler, A. H., Woodcock, C. E., Gopal, S., Schneider, A., Cooper, A., Baccini, A., Gao, F., and Schaaf, C.: Global land cover mapping from MODIS: algorithms and early results, Remote Sens. Environ., 83, 287-302, 2002.
Grégoire, J. M., Tansey, K., and Silva, J. M. N.: The GBA2000 initiative: developing a global burnt area database from SPOTVEGETATION imagery, Int. J. Remote Sens., 24, 1369-1376, doi:10.1080/0143116021000044850, 2003.

Giglio, L., van der Werf, G. R., Randerson, J. T., Collatz, G. J., and Kasibhatla, P.: Global estimation of burned area using MODIS active fire observations, Atmos. Chem. Phys., 6, 957974, doi:10.5194/acp-6-957-2006, 2006.

Giglio, L., Randerson, J. T., van der Werf, G. R., Kasibhatla, P. S., Collatz, G. J., Morton, D. C., and DeFries, R. S.: Assessing variability and long-term trends in burned area by merging multiple satellite fire products, Biogeosciences, 7, 1171-1186, doi:10.5194/bg-7-1171-2010, 2010.

Gobron, N., Pinty , B., Melin, F., Taberner , M., Verstraete, M. M., Robustelli, M., and Widlowski, J.-L.: Evaluation of the MERIS/ENVISAT FAPAR product, Adv. Space Res., 39, 105115, 2007.

Govaerts, Y., Pereira, J. M., Pinty, B., and Mota, B.: Impact of fires on surface albedo dynamics over the African continent, J. Geophys. Res., 107, 4629, doi:4610.1029/2002JD002388, 2002.

Govender, N., Trollope, W. S. W., and Van Wilgen, B. W.: The effect of fire season, fire frequency, rainfall and management on fire intensity in savanna vegetation in South Africa, J. Appl. Ecol., 43, 748-758, doi:10.1111/J.1365-2664.2006.01184.X, 2006.

Hoelzemann, J. J., Schultz, M. G., Brasseur, G. P., Granier, C., and Simon, M.: Global Wildland Fire Emission Model (GWEM): Evaluating the use of global area burnt satellite data, J. Geophys. Res., 109, D14S04, doi:10.1029/2003jd003666, 2004.

Ito, A. and Penner, J. E.: Global estimates of biomass burning emissions based on satellite imagery for the year 2000, J. Geophys. Res., 109, D14S05, doi:10.1029/2003jd004423, 2004.

Janhäll, S., Andreae, M. O., and Pöschl, U.: Biomass burning aerosol emissions from vegetation fires: particle number and mass emission factors and size distributions, Atmos. Chem. Phys., 10, 1427-1439, doi:10.5194/acp-10-1427-2010, 2010.

Jones, P. D. and Harris, I.: CRU Time Series (TS) high resolution gridded datasets, NCAS British Atmospheric Data Centre, 2011.

Keeling, C. D., Whorf, T. P., Wahlen, M., and Vanderplicht, J.: Interannual extremes in the rate of rise of carbon dioxide since 1980, Nature, 375, 666-670, 1995.

Kloster, S., Mahowald, N. M., Randerson, J. T., Thornton, P. E., Hoffman, F. M., Levis, S., Lawrence, P. J., Feddema, J. J., Oleson, K. W., and Lawrence, D. M.: Fire dynamics during the 20th century simulated by the Community Land Model, Biogeosciences, 7, 1877-1902, doi:10.5194/Bg-7-1877-2010, 2010.

Kopacz, M., Jacob, D. J., Fisher, J. A., Logan, J. A., Zhang, L., Megretskaia, I. A., Yantosca, R. M., Singh, K., Henze, D. K., Burrows, J. P., Buchwitz, M., Khlystova, I., McMillan, W. W., Gille, J. C., Edwards, D. P., Eldering, A., Thouret, V., and Nedelec, P.: Global estimates of CO sources with high resolution by adjoint inversion of multiple satellite datasets (MOPITT, AIRS, SCIAMACHY, TES), Atmos. Chem. Phys., 10, 855-876, doi:10.5194/acp-10-855-2010, 2010.

Langenfelds, R. L., Francey, R. J., Pak, B. C., Steele, L. P., Lloyd, J., Trudinger, C. M., and Allison, C. E.: Interannual growth rate variations of atmospheric $\mathrm{CO}_{2}$ and its $\delta^{13} \mathrm{C}, \mathrm{H}_{2}, \mathrm{CH}_{4}$, and $\mathrm{CO}$ between 1992 and 1999 linked to biomass burning, Global Biogeochem. Cy., 16, 1048-1069, 2002. 
Langmann, B., Duncan, B., Textor, C., Trentmann, J., and van der Werf, G. R.: Vegetation fire emissions and their impact on air pollution and climate, Atmos. Environ., 43, 107-116, 2009.

Lehsten, V., Tansey, K., Balzter, H., Thonicke, K., Spessa, A., Weber, U., Smith, B., and Arneth, A.: Estimating carbon emissions from African wildfires, Biogeosciences, 6, 349-360, doi:10.5194/bg-6-349-2009, 2009.

Lehsten, V., Harmand, P., Palumbo, I., and Arneth, A.: Modelling burned area in Africa, Biogeosciences, 7, 3199-3214, doi:10.5194/Bg-7-3199-20, 2010.

Matson, M. and Dozier, J.: Identification of Subresolution HighTemperature Sources Using a Thermal Ir Sensor, Photogramm. Eng. Rem. S, 47, 1311-1318, 1981.

Mieville, A., Granier, C., Liousse, C., Guillaume, B., Mouillot, F., Lamarque, J. F., Grégoire, J. M., and Petron, G.: Emissions of gases and particles from biomass burning during the 20th century using satellite data and an historical reconstruction, Atmos. Environ., 44, 1469-1477, 2010.

Mitchell, T. D. and Jones, P. D.: An improved method for constructing a database of monthly climate observations and associated high-resolution grids, Int. J. Climatol., 25, 693-712, 2005.

Mouillot, F. and Field, C. B.: Fire history and the global carbon budget: a 1 degrees $\times 1$ degrees fire history reconstruction for the 20th century, Glob. Change Biol., 11, 398-420, doi:10.1111/J.1365- 2486.2005.00920.X, 2005.

Mutlu, M., Popescu, S. C., Stripling, C., and Spencer, T.: Mapping surface fuel models using lidar and multispectral data fusion for fire behavior, Remote Sens. Environ., 112, 274-285, 2008.

Page, S. E., Siegert, F., Rieley, J. O., Boehm, H.-D. V., Jayak, A., and Limink, S.: The amount of carbon released from peat and forest fires in Indonesia during 1997, Nature, 420, 61-65, 2002.

Prentice, I. C., Kelley, D. I., Foster, P. N., Friedlingstein, P., Harrison, S. P., and Bartlein, P. J.: Modeling fire and the terrestrial carbon balance, Global Biogeochem. Cy., 25, GB3005, doi:10.1029/2010gb003906, 2011.

Ragland, K. W. and Aerts, D. J.: Properties of wood for combustion analysis, Bioresource Technol., 37, 161-168, 1991.

Ramankutty, N. and Foley, J. A.: Estimating historical changes in global land cover: Croplands from 1700 to 1992, Global Biogeochem. Cy., 13, 997-1027, 1999.

Rayner, P. J., Scholze, M., Knorr, W., Kaminski, T., Giering, R., and Widmann, H.: Two decades of terrestrial carbon fluxes from a Carbon Cycle Data Assimilation System (CCDAS), Global Biogeochem. Cy., 19, GB2026, doi:10.1029/2004GB002254, 2005.

Roy, D. P. and Boschetti, L.: Southern Africa Validation of the MODIS, L3JRC, and GlobCarbon Burned-Area Products, IEEE Trans Geosci Remote, 47, 1032-1044, doi:10.1109/Tgrs.2008.2009000, 2009.

Roy, D. P., Jin, Y., Lewis, P. E., and Justice, C. O.: Prototyping a global algorithm for systematic fire-affected area mapping using MODIS time series data, Remote Sens. Eviron., 97, 137-162, 2005.

Saatchi, S., Halligan, K., Despain, D. G., and Crabtree, R. L.: Estimation of forest fuel load from radar remote sensing, IEEE Transactions of Geoscience and Remote Sensing, 45, 17261739, 2007.

Schultz, M. G.: On the use of ATSR fire count data to estimate the seasonal and interannual variability of vegetation fire emissions, Atmos. Chem. Phys., 2, 387-395, doi:10.5194/acp-2-387-2002,
2002.

Schultz, M. G., Heil, A., Hoelzemann, J. J., Spessa, A., Thonicke, K., Goldammer, J. G., Held, A. C., Pereira, J. M. C., and van het Bolscher, M.: Global wildland fire emissions from 1960 to 2000, Global Biogeochem. Cy., 22, GB2002, doi:10.1029/2007gb003031, 2008.

Seiler, W. and Crutzen, P. J.: Estimates of Gross and Net Fluxes of Carbon between the Biosphere and the Atmosphere from Biomass Burning, Clim. Change, 2, 207-247, 1980.

Shea, R. W., Shea, B. W., Kauffman, J. B., Ward, D. E., Haskins, C. I., and Scholes, M. C.: Fuel biomass and combustion factors associated with fires in savanna ecosystems of South Africa and Zambia, J. Geophys. Res., 101, 23551-23568, 1996.

Simon, M., Plummer, S., Fierens, F., Hoelzemann, J. J., and Arino, O.: Burnt area detection at global scale using ATSR-2: The GLOBSCAR products and their qualification, J. Geophys. Res., 109, D14S02, doi:10.1029/2003jd003622, 2004.

Sitch, S., Smith, B., Prentice, I. C., Arneth, A., Bondeau, A., Cramer, W., Kaplan, J. O., Levis, S., Lucht, W., Sykes, M. T., Thonicke, K., and Venevsky, S.: Evaluation of ecosystem dynamics, plant geography and terrestrial carbon cycling in the LPJ dynamic global vegetation model, Glob. Change Biol., 9, 161-185, 2003.

Smith, B., Prentice, C., and Sykes, M.: Representation of vegetation dynamics in modelling of terrestrial ecosystems: comparing two contrasting approaches within European climate space, Global Ecol. Biogeogr., 10, 621-637, 2001.

Stocks, B. J. and Kauffman, J. B.: Biomass consumption and behavior of wildland fires in boreal, temperate, and tropical ecosystems: parameters necessary to interpret historic fire regimes and future fire scenarios, in: Sediment Records of Biomass Burning and Global Change, edited by: Clark, J. S., Cachier, H., Goldammer, J. G., and Stocks, B. J., NATO ASI Series, SpringerVerlag, Berlin, Germany, 169-188, 1997.

Tansey, K., Grégoire, J. M., Defourny, P., Leigh, R., Pekel, J. F. O., van Bogaert, E., and Bartholome, E.: A new, global, multiannual (2000-2007) burnt area product at $1 \mathrm{~km}$ resolution, Geophys. Res. Lett., 35, L01401, doi:10.1029/2007g1031567, 2008.

Thonicke, K., Venevsky, S., Sitch, S., and Cramer, W.: The role of fire disturbance for global vegetation dynamics: coupling fire into a Dynamic Global Vegetation Model, Global Ecol. Biogeogr., 10, 661-677, 2001.

Thonicke, K., Spessa, A., Prentice, I. C., Harrison, S. P., Dong, L., and Carmona-Moreno, C.: The influence of vegetation, fire spread and fire behaviour on biomass burning and trace gas emissions: results from a process-based model, Biogeosciences, 7, 1991-2011, doi:10.5194/bg-7-1991-2010, 2010.

van der Werf, G. R., Randerson, J. T., Giglio, L., Collatz, G. J., Kasibhatla, P. S., and Arellano Jr., A. F.: Interannual variability in global biomass burning emissions from 1997 to 2004, Atmos. Chem. Phys., 6, 3423-3441, doi:10.5194/acp-6-3423-2006, 2006.

van der Werf, G. R., Randerson, J. T., Giglio, L., Collatz, G. J., Mu, M., Kasibhatla, P. S., Morton, D. C., DeFries, R. S., Jin, Y., and van Leeuwen, T. T.: Global fire emissions and the contribution of deforestation, savanna, forest, agricultural, and peat fires (19972009), Atmos. Chem. Phys., 10, 11707-11735, doi:10.5194/acp10-11707-2010, 2010. 
van Leeuwen, T. T. and van der Werf, G. R.: Spatial and temporal variability in the ratio of trace gases emitted from biomass burning, Atmos. Chem. Phys., 11, 3611-3629, doi:10.5194/acp11-3611-2011, 2011.

Ward, D.: Combustion chemistry and smoke, in: Forest Fires - Behavior and Ecological Effects, edited by: Johnson, E. A. and Miyanishi, K., Academic Press, San Diego, CA, USA, 55-77, 2001.

Ward, D. E., Hao, W. M., Susott, R. A., Babbitt, R. E., Shea, R. W., Kauffman, J. B., and Justice, C. O.: Effect of fuel composition on combustion efficiency and emission factors for African savanna ecosystems, J. Geophys. Res., 101, 23569-23576, 1996.

Weedon, J. T., Cornwell, W. K., Cornelissen, J. H. C., Zanne, A. E., Wirth, C., and Coomes, D. A.: Global meta-analysis of wood decomposition rates: a role for trait variation among tree species?, Ecol. Lett., 12, 45-56, 2009.

Wiedinmyer, C., Quayle, B., Geron, C., Belote, A., McKenzie, D., Zhang, X. Y., O'Neill, S., and Wynne, K. K.: Estimating emissions from fires in North America for air quality modeling, Atmos. Environ., 40, 3419-3432, 2006.
Williams, A. C., Hanan, N. P., Neff, J. C., Scholes, R. J., Berry, J. A., Denning, A. S., and Baker, D. F.: Africa and the global carbon cycle, Carbon Balance and Management, 2, doi:10.1186/17500680-2-3, 2007.

White, M. A., Thornton, P. E., and Running, S. W.: A continental phenology model for monitoring vegetation responses to interannual climatic variability, Global Biogeochem. Cy., 11, 217-234, 1997.

Wooster, M. J., Roberts, G., Perry, G. L. W., and Kaufman, Y. L.: Retrieval of biomass combustion rates and totals from fire radiative power observations: FRP derivation and calibration relationships between biomass consumption and fire radiative energy release, J. Geophys. Res., 110, D24311, doi:10.1029/2005JD006318, 2005. 